\title{
ENVIRONMENTAL HEALTH ISSUES IN HIGH ALTITUDE AREAS OF SAGARMATHA (EVEREST) NATIONAL PARK AND BUFFER ZONE (SNPBZ)
}

\author{
Kumud Raj Kafle \\ Sanjay Nath Khanal \\ Kathmandu University, Nepal
}

\begin{abstract}
Sagarmatha (Everest) National Park, Nepal Himalayas, central part of the Hindu Kush Himalayas $(\mathrm{HKH})$ has been experiencing neo-environmental health problems in spite of being dubbed as "virgin land and virgin Himalayas with high altitude fresh people". So far, the common myth in the high altitude places has been only High Altitude Sickness (HAS), however other anthropogenically induced diseases such as diarrhoea, dysentery, Acute Respiratory Problem (ARP), unusual fever and parasitic worm infection have been commonly observed. Altogether 4 health stations with an average 7 hrs trekking apart are not sufficient to cater to more than 20,000 tourists per year with their guides \& porters and almost 6000 resident population.
\end{abstract}

Four health centers (Lukla 2850m, Namche $3450 \mathrm{~m}$, Khunde $3800 \mathrm{~m}$, and Pheriche $4300 \mathrm{~m}$ ) are the main health care units in this region. Poor accessibility and limited resources have caused further constrains to meet the demands of the visitors and locals.

The current researches and observations indicate that the waterborne diseases and diseases related to food are the new emerging health issues in the area. The trend is higher in lower altitude area than in the higher altitudes. Poor sanitation, huge amount of manure and its uses, traditional open toilets and open defecation, unhygienic pigsties and cattle sheds, poor drainage system in the major settlements are the major contributing factors. The recent studies have also indicated the acceleration of contamination of water and water bodies from different human induced sources. Awareness and education on health hygiene and sanitation, proper waste management, accessibility of potable water without further polluting the water sources in major trekking routes and settlements are necessary for maintaining good health as well as a sustainable social and economic development in SNPBZ.

\section{KEYWORDS}

SNPBZ, health issues, sanitation

\section{INTRODUCTION}

Hindu-Kush Himalayan region extends about $2400 \mathrm{Km}$ from east to west and the Nepal Himalayan Range covers about $800 \mathrm{Km}$. Within a span of $200 \mathrm{Km}$, its altitudinal variation from South to North- ranges from $70 \mathrm{~m}$ to $8848 \mathrm{~m}$ (Mt. Everest). The Sagarmatha National Park lies in Solukhumbhu district of Nepal, southern part of the Mt. Everest. The park and 
buffer zone cover an area of about 1148 sq. $\mathrm{km}$ and 275 sq. $\mathrm{km}$ area respectively. The park is characterized by rugged orographic topography, glaciers, crystal clear waterbodies, and interesting biological species (Jha, 2010). Tourism (trekking and expeditions) is a major business in this region.

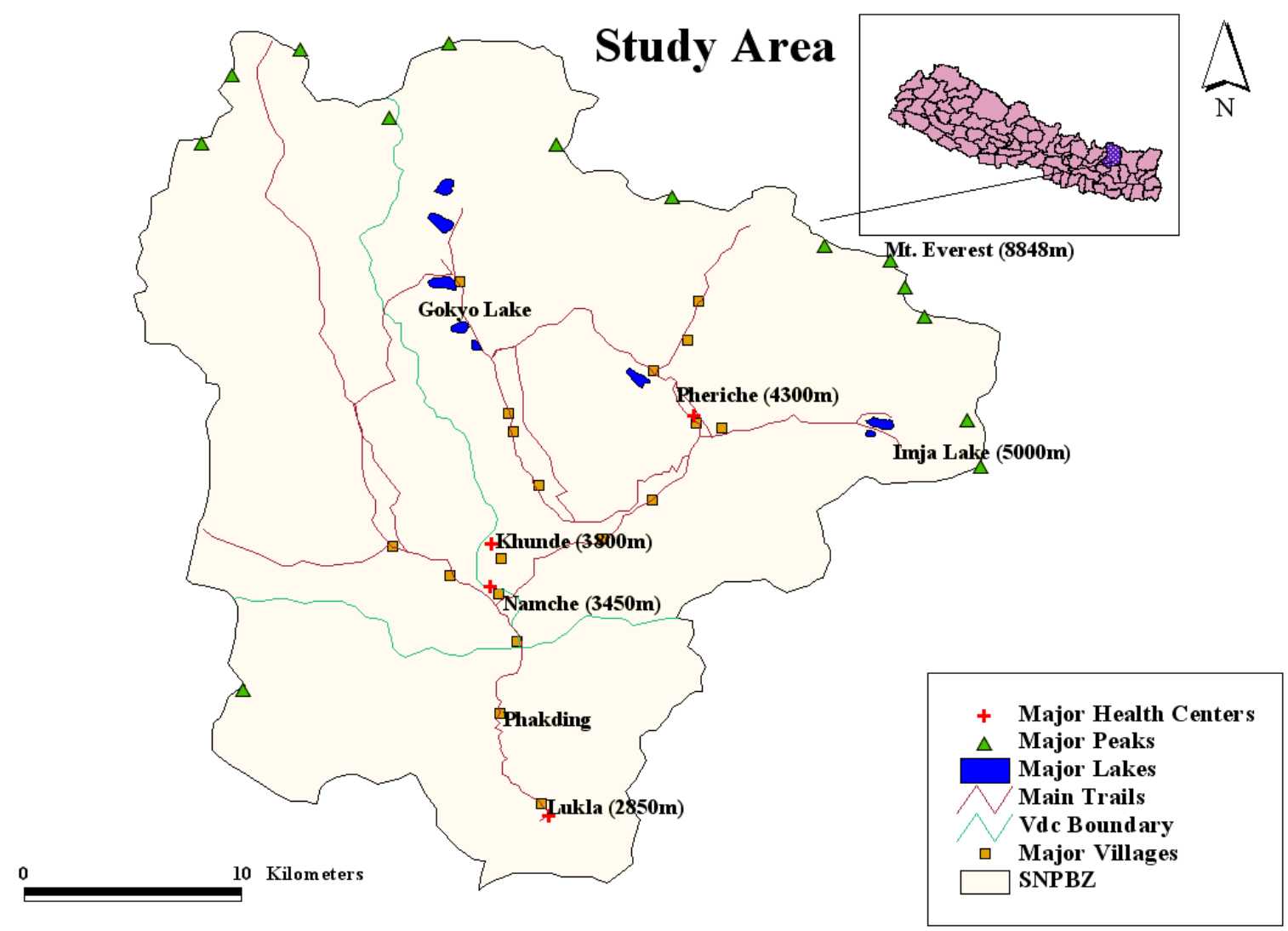

Figure 1. Study area map.

The major trekking routes are to the Everest Base Camp (EBC), Gokyo Lake and Island Peak. There are two peak seasons: pre-monsoon (March, April and May) and post-monsoon (August, September and October). Over 1,333 households are present in the region. Almost $50 \%$ households are directly benefited from tourism business. The number of international visitors has been on the rise (Bhuju, 2010). 
Table 1. Trekking staffs involvement in SNPBZ

\begin{tabular}{|c|l|l|}
\hline $\begin{array}{c}\text { S. } \\
\text { N. }\end{array}$ & \multicolumn{1}{|c|}{ Involvement } & $\begin{array}{c}\text { Number of } \\
\text { person } \\
\text { engaged }\end{array}$ \\
\hline 1 & Trekking Supporting Staff & 5,873 \\
\hline 2 & Transportation Porter & 8,417 \\
\hline 3 & House Employee & 8,800 \\
\hline 4 & Construction Worker & 5,250 \\
\hline 5 & Other & 245 \\
\hline 6 & Total & 28,585 \\
\hline
\end{tabular}

Source: Sharma, 2008

The Mt. Everest region has been experiencing neo-environmental health problems in spite of being dubbed as "virgin land and virgin Himalayas with high altitude fresh people". So far, the common myth in the high altitude places has been only High Altitude Sickness (HAS), however other anthropogenically induced diseases such as diarrhoea, dysentery, acute respiratory problem, unusual fever and parasitic worm infection have been commonly observed. Altogether 4 health centers with an average of 7 hrs trekking apart are not sufficient to cater to more than 20,000 tourists per year with their guides \& porters and almost 6000 resident population.

In the last few years, a number of food and water related diseases have been reported by visitors (http://www.mounteverest.net, 2005) as well the locals (Sherpa, 2010). Contamination in water bodies in the Sagarmatha National Park and its Buffer Zone (SNPBZ) has accelerated in recent years. Recent research has shown (Ghimire et al. 2010), that 13 percent of water samples has bacterial contamination. The research has further reported that even mineral water is contaminated with bacteria. Poor toilet conditions and use of manures are the major cause of water contamination. $20 \%$ of households don't even have toilets. Out of 2,197 tons of manure that is produced in the region annually, eight tons of manure is used per hectare of arable land. The excessive use of manure contaminates the water bodies (NGO forum, 2009). High number of open toilets and unmanaged solid wastes are major sources of environmental degradation in the Sagarmatha region. Although human waste have not been taken seriously as a source of pollution, the accumulated solid excreta in the glaciers and base camp have increased and it has started polluting the environment. The amount of urine release per person per day at high altitude was estimated to be 2.16 litre (Tabei, 2001). Khanal et al. (2010) also indicated that the rainfall washes away the faecal material of toilets without septic tanks and the pollution is caused by anthropogenic activities, foremost through waste water, especially from open toilets and solid waste disposal. Indoor cooking practices, personal hygiene of cooking members of hotels and lodges, kitchen utensils are also major contributing factors for the contamination in food. These factors are observed major sources of pollution in water bodies and contamination in SNPBZ region during the field study period.

\section{HEALTH SERVICES IN SNPBZ}


Four Health Centers (Lukla 2850m, Namche 3450m, Khunde $3800 \mathrm{~m}$, and Pheriche $4300 \mathrm{~m}$ ) are the main health care units in this region. Among these, three are non governmental hospital and provide health service throughout the year to the local people as well as the visitors (see Table 2). Most of the expedition teams have their own doctors and medicines and they are not generally visited in those health centers. More than 20,000 visitors and their support staff (Porters and Guides) along with the local residents depend on these hospitals. However, the health centers in Solukhumbu district in general, in the government health services system are understaffed (with $43 \%$ still lying vacant) and with limited services and facilities (see Table 3).

It is obvious that every trekking season is the most potential time for disease out breaks because of intense social and economic activities of tourism. According to the previous health records according to MoHP, 2009, the major health problems in the region are worm infestation (8.9\%), Upper Respiratory Track Infection (URTI) $(6.06 \%)$ and gastritis $(5.78 \%)$ followed by diarrhoea and dysentery (sum of 5.8\%). At present, the incidence of some of these diseases has increased.

Table 2. Major health centers and their services/provisions

\begin{tabular}{|c|c|c|c|c|c|}
\hline S. N. & $\begin{array}{l}\text { Name of } \\
\text { Health } \\
\text { Clinic } \\
\end{array}$ & Location & $\begin{array}{l}\text { Trekking } \\
\text { route }\end{array}$ & $\begin{array}{l}\text { Area } \\
\text { covered }\end{array}$ & $\begin{array}{l}\text { Key } \\
\text { activities }\end{array}$ \\
\hline 1 & $\begin{array}{l}\text { Pasang } \\
\text { Lamhu } \\
\text { Hospital }\end{array}$ & $\begin{array}{l}\text { Lukla } \\
(2850 \mathrm{~m})\end{array}$ & $\begin{array}{l}\text { Gateway to } \\
\text { Everest } \\
\text { region } \\
\text { Trekking }\end{array}$ & $\begin{array}{l}\text { Lukla, } \\
\text { Chaurikhaka }\end{array}$ & $\begin{array}{l}\text { Indoor, } \\
\text { OPD } \\
\text { services }\end{array}$ \\
\hline 2 & $\begin{array}{l}\text { Namche } \\
\text { Health Post }\end{array}$ & $\begin{array}{l}\text { Namche } \\
\text { bazaar } \\
(3450 \mathrm{~m})\end{array}$ & $\begin{array}{l}\text { Base camp, } \\
\text { Gokyo Lake, } \\
\text { Island peak }\end{array}$ & $\begin{array}{l}\text { Namche and } \\
\text { adjacent } \\
\text { villages }\end{array}$ & $\begin{array}{l}\text { Indoor, } \\
\text { OPD } \\
\text { services }\end{array}$ \\
\hline 3 & $\begin{array}{l}\text { Khunde } \\
\text { Hospital }\end{array}$ & $\begin{array}{l}\text { Khumjung } \\
\text { Valley } \\
(3800 \mathrm{~m})\end{array}$ & $\begin{array}{l}\text { Base camp, } \\
\text { Gokyo Lake, } \\
\text { Island peak }\end{array}$ & $\begin{array}{l}\text { Khumjung, } \\
\text { Namche, } \\
\text { Chaurikharka }\end{array}$ & $\begin{array}{l}\text { Indoor, } \\
\text { OPD } \\
\text { services }\end{array}$ \\
\hline 4 & $\begin{array}{l}\text { Pheriche } \\
\text { Health post }\end{array}$ & $\begin{array}{l}\text { Pheriche } \\
(4300 \mathrm{~m})\end{array}$ & $\begin{array}{l}\text { Base camp, } \\
\text { Island peak }\end{array}$ & $\begin{array}{l}\text { Pheriche, } \\
\text { Dhingboche, } \\
\text { Somare, } \\
\text { Lobuche, } \\
\text { Gorakhshep } \\
\text { and Everest } \\
\text { Base camp }\end{array}$ & $\begin{array}{l}\text { Indoor, } \\
\text { OPD } \\
\text { services }\end{array}$ \\
\hline
\end{tabular}

Source: MoHP, 2009 
Table 3. Status of the health workers in Solukhumbu district

\begin{tabular}{|l|l|l|l|}
\hline Institution & $\begin{array}{l}\text { No. of health } \\
\text { worker position }\end{array}$ & $\begin{array}{c}\text { No. of } \\
\text { Occupancy }\end{array}$ & $\begin{array}{l}\text { Vacant } \\
\text { post }\end{array}$ \\
\hline $\begin{array}{l}\text { Public Health } \\
\text { office }\end{array}$ & 18 & 13 & 5 \\
\hline $\begin{array}{l}\text { District } \\
\text { Hospital }\end{array}$ & 24 & 17 & 7 \\
\hline $\begin{array}{l}\text { Primary } \\
\text { Health Care } \\
\text { Centre }\end{array}$ & 24 & 13 & 11 \\
\hline Health Post & 54 & 38 & 16 \\
\hline $\begin{array}{l}\text { Sub-health } \\
\text { Post }\end{array}$ & 69 & 26 & 43 \\
\hline Total & 189 & 107 & 82 \\
\hline
\end{tabular}

Source: MoHP, 2009

\section{FIELD TRIP}

A 15 days field trip was conducted for the study during April 2010 covering the areas from Lukla (2,850m) to Imja Lake (5,000m), Everest Base Camp and Kalapathar (5,640m).

During this trip, data was collected from all the four health centers along the trekking routes. Field observation and documentation, interviews with doctors, questionnaire surveys from tourists were conducted.

\section{RESULTS AND DISCUSSION}

A total of 1,644 patients' (15\%) data of spring 2010 from health centers were analyzed. Data related to pregnancy and delivery cases were not included.

The data were categorized into 5 classes:

- Diseases Related to Food and Water (DRFW)

- Diseases Related to Air Pollution (DRAP)

- Diseases Related to the High Altitude (DRHA)

- Diseases Related to the Cold (DRC)

- Diseases Related the Load and Exertion (DRLE)

It was found that DRFW accounted for $36.8 \%$ (Gastritis was predominant $13.18 \%$, followed by fever $10.45 \%$, diarrhea and dysentery is $9.34 \%$, worms and boils $3.84 \%$. whereas DRAP (eye infection, allergies and acute respiratory infection) accounted for 5.4\% (see Figure 2). 


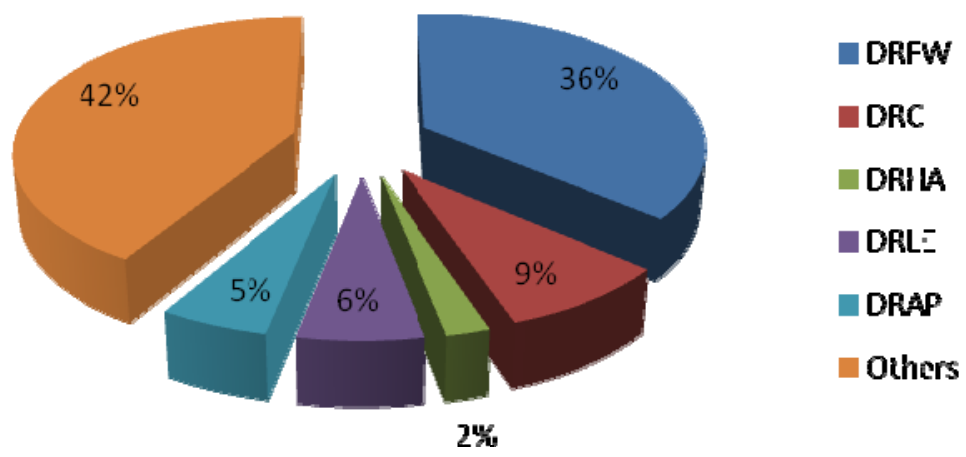

Figure 2. Major disease categories in SNPBZ area.

The incidence of DRFW is $30.76 \%$ in Pheriche $(4,300 \mathrm{~m})$ and $40.24 \%$ in Lukla $(2,850 \mathrm{~m})$. Similarly DRAP is $0.00 \%$ in Pheriche and $8.05 \%$ in Lukla (see Table 4). This indicates that the trend of DRFW and DRAP are higher in lower elevation. This may be due to higher temperature in lower elevations and human interventions/activities are also much more than that in upper elevation areas. Similarly, the higher elevation areas are relatively moist and the incidence of DRAP is less.

Table 4. Diseases in different health centers (HC) along the main trekking routes

\begin{tabular}{|c|c|c|c|c|c|c|}
\hline S. N. & Categories & Diseases & $\begin{array}{l}\text { \% in } \\
\text { Pheriche } \\
\text { HC }\end{array}$ & $\begin{array}{l}\text { \% in } \\
\text { Khunde } \\
\text { HC }\end{array}$ & $\begin{array}{l}\text { in } \\
\text { Namche } \\
\text { HC }\end{array}$ & $\begin{array}{l}\text { in } \\
\text { Lukla } \\
\text { HC }\end{array}$ \\
\hline $\mathbf{2}$ & $\begin{array}{c}\text { Diseases } \\
\text { relevant to Food } \\
\text { and Water }\end{array}$ & $\begin{array}{c}\text { Diarrhoea, } \\
\text { Dysentery, } \\
\text { Worms, } \\
\text { Gastritis } \\
\text { and fever }\end{array}$ & 30.76 & 31.82 & 34.60 & 40.24 \\
\hline 3 & $\begin{array}{c}\text { Disease relevant } \\
\text { to Air Pollution } \\
\text { Infection, } \\
\text { Allergy, } \\
\text { ARI }\end{array}$ & 0.00 & 4.90 & 5.02 & 8.05 \\
\hline 4 & $\begin{array}{c}\text { Diseases } \\
\text { relevant to cold }\end{array}$ & $\begin{array}{c}\text { Common } \\
\text { Cold }\end{array}$ & 20.37 & 0.00 & 7.44 & 5.99 \\
\hline 3 & $\begin{array}{c}\text { Disease relevant } \\
\text { to Load and } \\
\text { Exertion }\end{array}$ & $\begin{array}{c}\text { Bodyache, } \\
\text { Muscular } \\
\text { Pain, Chest } \\
\text { pain }\end{array}$ & 18.70 & 0.00 & 3.53 & 4.28 \\
\hline $\begin{array}{c}\text { Diseases } \\
\text { relevant to } \\
\text { High Altitude }\end{array}$ & $\begin{array}{c}\text { AMS and } \\
\text { Headache }\end{array}$ & 12.88 & 0.00 & 0.00 & 0.00 \\
\hline
\end{tabular}




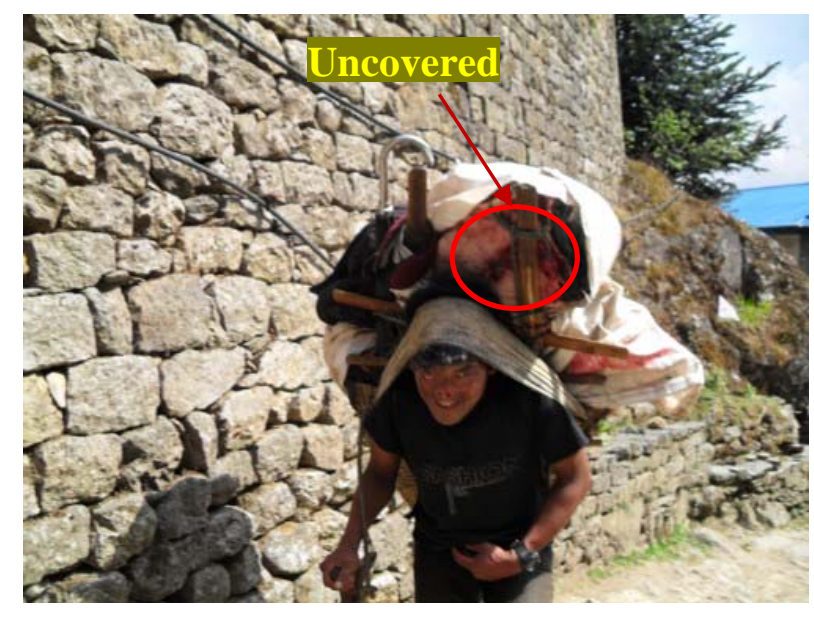

Figure

3. $\quad$ Meat

Transporting from Southern Part of the SNPBZ area.

Most of packed/ tinned foods are brought from Kathmandu. It was observed that meat and dairy products are brought from southern part of the region which may take 2 to 3 days from Lukla. The means of transportation is either by porters or by animals like Jyokko (Hybrids of cow and yak) and yaks. Meat products may be contaminated during transportation as these were seen carried without being covered (see Figure 3).

The DRHA and DRC were prominent at higher elevation. It is obvious that in higher elevation the temperature and atmospheric pressure are lower than that of the lower elevation areas. The major age group who suffers from these diseases is between $18-50$ years $(65.64 \%)$. It was found that $58.86 \%$ of sufferers were male and it is because of the male dominancy in trekking business.

It was also found that more than $20 \%$ foreigners were affected by anyone of the diseases during their trek. Recent research also supports that the pollution in water bodies is in increasing trend towards the lower elevations.

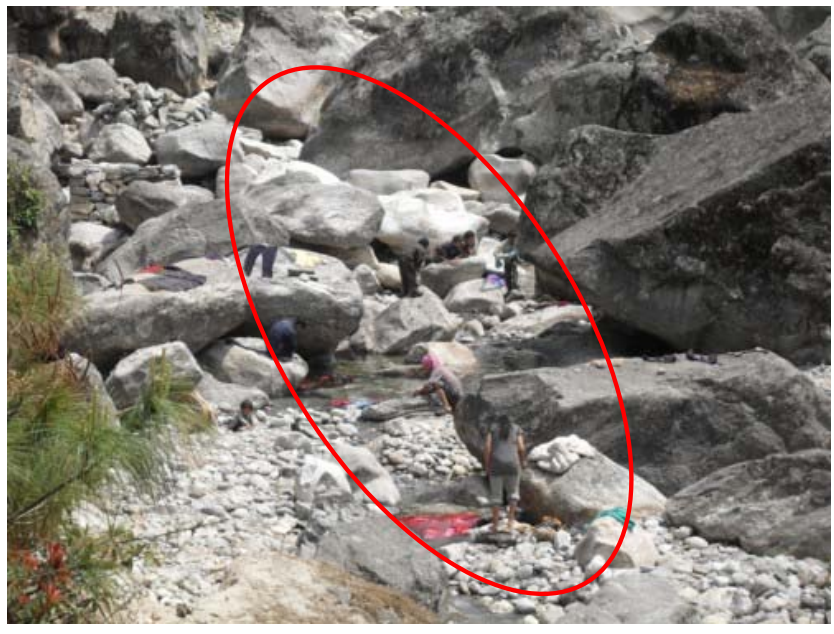

Figure 4. Cloth washing at the tributaries.

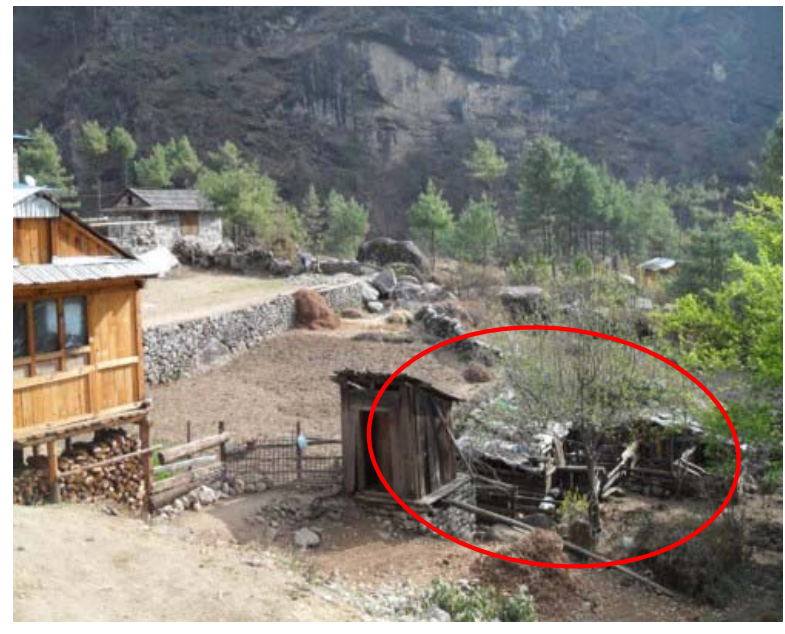

Figure 5. Pigsties on the river terrace. 


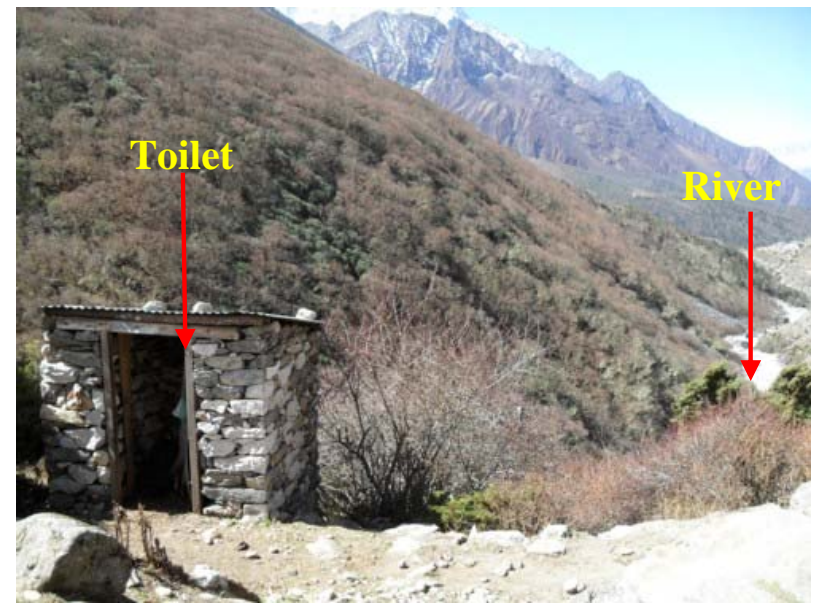

Figure 6. Toilet on the terrace of the river (at Somara).

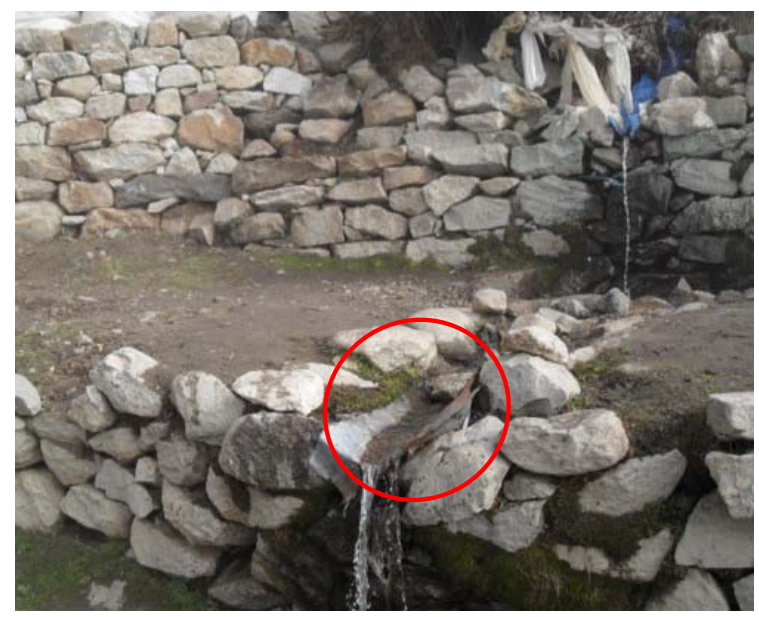

Figure 7. Rusted tin sheet (drinking water) at Dhingboche.

Toilets near to the river courses, open defecations, unhygienic pigsties and cattle sheds, poor drainage system in the major settlements are the main contributing factors that had been observed during the field trip. The major problems observed in villages are in the table (see Table 5)

Table 5. Observed environmental problem along the main trekking route villages

\begin{tabular}{|l|l|l|}
\hline $\begin{array}{l}\text { Trekking } \\
\text { Route Villages }\end{array}$ & Environmental Problems & Indicators \\
\hline Lukla & $\begin{array}{l}\text { Open defecation, Cloth washing } \\
\text { in tributaries, poor drainage } \\
\text { system, }\end{array}$ & $\begin{array}{l}\text { Washing in river, excreta in the } \\
\text { field, wet and water in the village } \\
\text { route }\end{array}$ \\
\hline Phakding & $\begin{array}{l}\text { Poor drainage, open } \\
\text { urination, less toilets }\end{array}$ & $\begin{array}{l}\text { Wet and water in the village route, } \\
\text { wet and smell along the route }\end{array}$ \\
\hline TokTok & $\begin{array}{l}\text { Unhygienic pigsties, metal } \\
\text { contamination in water, toilets } \\
\text { near by the river }\end{array}$ & $\begin{array}{l}\text { Pigsties in riverbank terrace, } \\
\text { constructed toilet near by the river }\end{array}$ \\
\hline Dingboche & $\begin{array}{l}\text { Open defecation, Cloth Washing } \\
\text { sheds, poor drainage system }\end{array}$ & $\begin{array}{l}\text { Washing in river, cattle in } \\
\text { elsewhere, wet and water in trails } \\
\text { sources and cattle sheds }\end{array}$ \\
\hline Chhukum & Toilets near to the river & $\begin{array}{l}\text { Wet and water around route, } \\
\text { rusted tin used on the drinking } \\
\text { water }\end{array}$ \\
\hline Lobuche & $\begin{array}{l}\text { Poor drainage, Cloth wasting in } \\
\text { the river, unmanaged cattle } \\
\text { sheds, dumping area near to river }\end{array}$ & $\begin{array}{l}\text { Wet and water around the village, } \\
\text { washing in the river, dumping pit } \\
\text { on the riverbank }\end{array}$ \\
\hline
\end{tabular}




\section{CONCLUSION}

There are several environmental and health-related issues which need to be addressed .The diseases in SNPBZ area can be categorized into 5 classes. DRFW are emerging health issues in the area and the distribution of diseases is related to altitude. DRFW and DRAP are more pronounced in lower elevation areas whereas DRHA and DRC are more pronounced in high altitude areas. Awareness and education on health hygiene and sanitation, proper waste management, accessibility of potable water without further polluting the water sources in major trekking routes and settlements, adequate health services are necessary for maintaining good health as well as a sustainable social and economic development in SNPBZ.

\section{ACKNOWLEDGEMENT}

The study was conducted as a component of joint $\mathrm{Ph}$. D. program of Kathmandu University and LAQUA group Sweden (constituting Linnaeus University formerly Kalmar University, Lund University and Kristianstad University) to give us an opportunity to visit and collect the data from SNPZ area. We are especially grateful to Prof. Dr. William Hogland and Prof. Dr. Lenart Martinson of LAQUA group Sweden. We are also thankful to Dinesh Manandhar from Kathmandu University to help us in the field trip.

\section{REFERENCES}

[1] Bhuju, U. K., 2010, Visitors Survey in Sagarmatha National Park, Nepal Contemporary Research in Sagarmatha (Mt. Everest) Region, Nepal, 1, Nepal Academy of Science and Technology, Khumaltar, Lalitpur.

[2] Ghimire N. P., B. B. Shrestha, G. U. Caravello and P. K. Jha, 2010. Sources of Water Pollution in Sagarmatha National Park and Buffer Zone, Nepal, Contemporary Research in Sagarmatha (Mt. Everest) Region, Nepal, 103-104., Nepal Academy of Science and Technology, Khumaltar, Lalitpur.

[3] http://www.mounteverest.net, 2005, BaseCampMD - Khumbu cough, HAPE and chilblains on Everest's South Side, April 28, 2005.

[4] Jha, P. K. 2010. An Overview of Sagarmatha (Mt. Everest) Region, Nepal. Contemporary Research in Sagarmatha (Mt. Everest) Region, Nepal,p.1, Nepal Academy of Science and Technology, Khumaltar, Lalitpur.

[5] Khanal S. N., R.B. Kayastha, R. K. Maskey, K. R. Kafle, S.Bhochhibhoya, G. Chaudhari, R. Pandey and Y. Sherpa, 2010, A Study on Solid Waste Management in Sagarmatha National Park and Buffer Zone (SNPBZ)., Contemporary Research in Sagarmatha (Mt. Everest) Region, Nepal, 91-93., Nepal Academy of Science and Technology, Khumaltar, Lalitpur.

[6] Ministry of Health \& Population (MoHP), 2009, Department of Health Services, District Health Office (DHO) Solukhumbu, Nepal, District Health Profile and Annual Report 6-39.

[7] NGO Forum, 2009, The Himalayan Times and Annapurna Post, Nepal: water bodies in Everest region contaminated, survey, April 21, 2009.

[8] Sharma, T. R. 2008, Updates on the Sagrmatha National Park - Presentation Made at the Sagarmatha Tourism Coordination Forum - Third Meeting held on June 20, 2008 in Kathmandu, and Organized by Sagarmatha National Park and Buffer Zone Management Committee, Department of National Parks and Wildlife Conservation, 
and Nepal Tourism Board with the supports of HKKH - IUCN Nepal, Nepal Mountaineering Association, and trekking Agencies' Association of Nepal.

[9] Sherpa K., 2010, Local resident as well as Doctor, Interview taken at Khunde Hospital, Khumjum Valley.

[10] Tabei, J. 2001. Climbers' impact on the natural environmental in mountain areas and environmental conservation: Present situation of wasters left by climbers in the Mount Everest region. In: Proceeding of the International Symposium on the Himalayan Environment: Mount sciences and Ecotourism/Biodiversity. Eds.T.Watanatse, S. Sircroff, N. R. Khanal and M. P. Gautam. Hokkaido University, Japan and Tribhuvan University, Nepal, 6-13. 